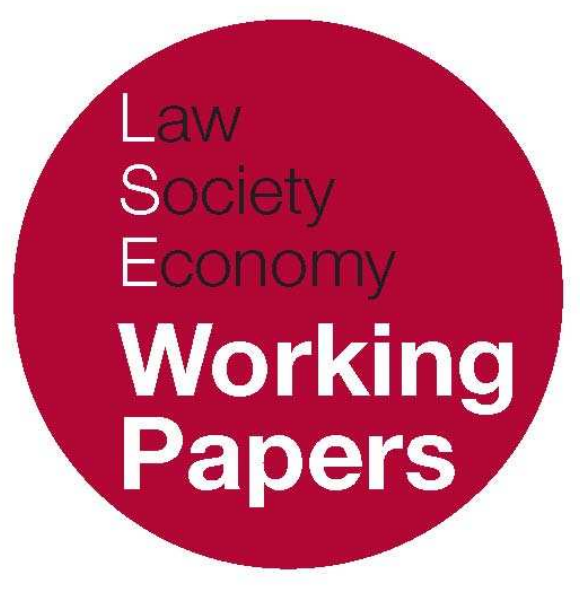

Managing the Intersection of Utilities

Regulation and EC Competition Law

\author{
Giorgio Monti
}

LSE Law, Society and Economy Working Papers 8/2008

London School of Economics and Political Science

Law Department

\begin{abstract}
This paper can be downloaded without charge from LSE Law, Society and Economy Working Papers at: www.lse.ac.uk/collections/law/wps/wps.htm and the Social Sciences Research Network electronic library at: http://ssrn.com/abstract=1111969.

(C) Giorgio Monti. Users may download and/or print one copy to facilitate their private study or for non-commercial research. Users may not engage in further distribution of this material or use it for any profit-making activities or any other form of commercial gain.
\end{abstract}




\title{
Managing the Intersection of Utilities Regulation and EC Competition Law
}

\author{
Giorgio Monti*
}

\begin{abstract}
Utilities regulation in the Member States is always subject to the application of EC competition law. However, this undermines the effectiveness of utilities regulation and a more flexible standard should be devised by the European Courts. The Court of First Instance has an opportunity to do so in two pending appeals where the Commission found an infringement of Article $82 \mathrm{EC}$ after the actions of the dominant firm had been endorsed by the national telecommunications regulator. The grounds for affording greater latitude to regulators are threefold: first the regulator should be free to make decisions on economic grounds that support dynamic over allocative efficiency; second it should also be free to make decisions on non-economic grounds to prioritise other objectives at the expense of competition; and third the present scope of EC competition law is so wide that in several instances the Commission acts in a regulatory manner, stepping over tasks best left to the regulator. No general principle is recommended to demarcate the borderline between competition law and sector regulation but a case-by-case assessment should be carried out to determine whether the application of competition law would cut across the policy choices reached by the utilities regulator, and competition law should not apply when it would harm the regulatory goals.
\end{abstract}

\section{INTRODUCTION}

The question addressed in this essay can be captured by a recent exchange of views between Telefónica and the Commission - the former had considered its price schemes immune from antitrust action having been subjected to sector

\footnotetext{
* Law Department, London School of Economics. An earlier draft of this paper was presented at the September meeting of the Competition Law Scholars' Forum. I am grateful for the comments raised on that occasion. Thanks also to Mel Marquis for commenting on a draft version of this paper. Any errors remain mine.
} 
specific regulation, and so it reacted with some force when the Commission imposed a fine on it for abuse of a dominant position through a price squeeze: ${ }^{1}$

'Telefónica finds itself squeezed between two regulators - the national regulator and the European Commission - which are at odds with each other. As a result, the decision by the Commission creates enormous uncertainty about the role played by the regulatory bodies and the competition authorities in the telecommunications sector, throwing into question the supervisory functions of the Spanish authorities. The legal uncertainty created by this decision will inevitably affect Telefónica's and other operators' ability to launch new products and services, with a direct impact on the entire European telecommunications sector to the detriment of European consumers. $^{2}$

The Commission was quick to respond to these arguments, in the following manner:

There is nothing extraordinary or exceptional in the fact that the Commission and the [national telecommunications regulator] found different results: in the telecommunications sector regulators put in place ex ante regulatory mechanisms allowing competition to develop, but can only do this on the basis of market and cost forecasts. In so doing regulators lessen, but cannot entirely eliminate the risk of anti-competitive behaviour. Competition authorities act ex post, using historical data on effectively incurred costs. Accordingly, in many Member States, competition authorities have investigated and sanctioned expost anti-competitive conducts in the regulated telecommunications markets, including broadband access. ${ }^{3}$

While acknowledging that EC competition law can apply in regulated industries, and that this application is generally beneficial, I shall explore whether some limits on its application may be desirable. The essay is organised in the following manner: in part two I explain the rationale for the concurrent application of regulation and antitrust as well as its implications. In part three I argue that the overlap may not always be defensible, in that action or inaction by the regulator should not always be disturbed by the application of competition law, either because the regulator should be free to trade-off different competition considerations (e.g. choosing to favour dynamic over allocative efficiency) or to undermine competition in favour of other valued non-competition considerations (e.g. energy security over competitive markets). In part four I question the breadth of the application of EC competition law from a different perspective, noting that

${ }^{1}$ COMP/38.784 - Telefonica SA(broadband) 4 July 2007; Press Release IP/07/1011 (4 July 2007).

2 Telefónica Press release, 4 July 2007 available at: http://saladeprensa.telefonica.es/documentos/ 070704_Press_Release_EU_decision_ing.pdf.

${ }^{3}$ MEMO/07/274 Antitrust: Commission decision against Telefónica - frequently asked questions 4 July 2007. 
rather than merely applying settled legal principles, the Commission has a tendency to apply competition law in a 'regulatory' manner when challenging conduct in network industries. This serves to increase the overlap between competition law and regulation, an approach that may frustrate a national regulator's efforts further. Accordingly I conclude that there should be some limits placed upon the application of competition law, suggesting that the European Courts should develop the case law so as to allow them and national courts to determine on a case by case basis whether competition law should not apply in a situation where a regulator has already intervened. ${ }^{4}$

\section{THE SUPREMACY OF EC COMPETITION LAW}

\section{LEGAL JUSTIFICATIONS}

One test case over the issue discussed in this paper is currently in front of the CFI and arises from the Deutsche Telekom decision. ${ }^{5}$ In brief, the facts are these: Deutsche Telekom (DT) has an obligation to unbundle the local loop to allow competitors to offer competing services and the wholesale price for this was approved by the National Regulatory Authority. DT's retail prices for PSTN (land line) and ISDN (digital line) subscription were capped too. It transpired that the approved wholesale and retail prices were such that a competitor seeking access to the local loop would have to pay a wholesale price so high that in order to recoup it in the downstream retail market it would have to set a retail price higher than offered by DT, so resulting in a price squeeze, contrary to Article 82. One of DT's arguments was that it had relied on the regulator's directions and so assumed its pricing policies were lawful. This argument was quickly cast aside by the Commission in the following way: 'the competition rules may apply where the sector-specific legislation does not preclude the undertakings it governs from engaging in autonomous conduct that prevents, restricts or distorts competition.' 6 This reasoning follows the instructions in Ladbroke, where the ECJ held that '[w] hen the Commission is considering the applicability of Articles [81] and [82] of the Treaty to the conduct of undertakings, a prior evaluation of national legislation

\footnotetext{
4 The relationship between national regulation and national competition law, in particular the coordination between the National Competition Authority and National Regulatory Authorities is outside the scope of this paper. Different countries have opted for different patterns. The OECD notes the following: in Mexico the competition authority carries out certain parts of the assessment (e.g. analysis of market power) and the regulator then applies SSR; the UK has opted for concurrent powers of the OFT and NRA; in Australia senior officials from regulated industries serve as associates in the ACCC; in Ireland there are cooperation channels between NRA and competition authority; in The Netherlands the NRA and competition authority are merged. OECD Global Forum on Competition The Relationship Between Competition Authorities and Sectoral Regulators - Issues Paper DAF/COMP/GF(2005)2 (available at: http://www.oecd.org/dataoecd/58/7/34375749.pdf).

${ }^{5}$ Deutsche Telekom AG [2003] OJ L263/9 (Case T-271/03, appeal pending [2003] OJ C 264/29).

${ }^{6} \mathrm{ibid}$, at [54].
} 
affecting such conduct should therefore be directed solely to ascertaining whether that legislation prevents undertakings from engaging in autonomous conduct which prevents, restricts or distorts competition. ${ }^{7}$ Note that it is not relevant whether the national law originates from national procedures or is national law which is implementing an EC Directive, the only consideration is whether the undertaking's action was its own or whether it was compelled to act in an anticompetitive way by state law.

Accordingly, the legal position is as follows: provided the regulator does not compel the undertaking to act in a specific way which is in breach of Articles 81 and 82 , then the undertaking remains subject to EC competition law, while if the undertaking is forced to act in ways that infringe Articles 81 and 82, then the Member State is responsible for the breach, relying on a combined reading of Articles 3(1)(g), 10 and 81 or $82,{ }^{8}$ and the undertaking escapes without a penalty. When the State is in breach, the Commission may act by way of the procedures in Article 226, or national competition authorities may take action and disapply national law that is incompatible with EC competition law. ${ }^{9}$ If state law encourages an infringement of the competition rules, then both the state and the undertakings are responsible, and both may face fines and damages claims in private law. ${ }^{10}$

As Professor Larouche points out, this position is justified by the constitutional structure of the Treaty. ${ }^{11}$ His views are confirmed by the $\mathrm{O} 2$ Decision where the application of Article 81 in the telecoms sector was considered: '[s]ubject to the principle of the primacy of Community law, the national regulatory framework and the EU competition rules are of parallel and cumulative application. National rules may neither conflict with the EU competition rules nor can compatibility with national rules and regulations prejudice the outcome of an assessment under the EU competition rules. ${ }^{12}$ This is probably the more fundamental justification than the technical reason that the Commission offered in Deutsche Telekom, but both statements are complementary and suggest that the CFI is likely to rule against Deutsche Telekom and uphold the concurrent application of utilities regulation and competition law.

The implication of this doctrinal stance is that because DT was not obliged to set prices that resulted in a margin squeeze, it had a duty to return to the NRA and ask for it to approve prices that would not have resulted in a price squeeze. In the

7 Joined cases C-359/95 P and C-379/95 P Commission and France v Ladbroke Racing Ltd [1997] ECR I6265, at [35] (emphasis added).

${ }^{8}$ The case law is summarised in D. Chalmers et al, European Union Law: Text and Materials (Cambridge: Cambridge University Press, 2006) 1116-1122. A more detailed account is J. Baquero Cruz 'The State Action Doctrine' in G. Amato and C-D Ehlermann (eds.), EC Competition Law - A Critical Assessment (Portland, Or.: Hart, 2007).

${ }^{9}$ Case C-198/01 Consorzio Industrie Fiammiferi [2003] ECR I-8055.

10 ibid.

${ }^{11}$ P. Larouche 'Contrasting Legal Solutions and the Comparability of EU and US Experiences' TILEC Discussion Paper (DP 2006/028) 10-11.

12 T-Mobile Deutscbland/O2 Germany [2004] OJ L75/32, at [22] (the principle was not challenged on appeal to the CFI). 
Commission's words, 'DT could have avoided the margin squeeze by increasing retail charges for analogue and ISDN connections, because it was entitled to apply to the regulatory authority at any time asking for adjustments to charges. ${ }^{13}$ This obligation looks like an extension of the duty imposed on a dominant undertaking not to abuse one's dominant position, indeed the CFI has even indicated that dominant firms may even have to modify their behaviour to avoid abuse regardless of whether the Commission has adopted a decision. ${ }^{14}$ Moreover, the obligation on regulated firms to consult the regulator when they can foresee an infringement of competition law is not dependent on the firm being in a dominant position, and applies to Article 81 infringements too, because the question being considered is merely whether the undertaking was responsible for the infringement, and so long as there is room for avoiding an infringement of the competition rules, the undertaking has a duty to explore those options.

The implications of this legal position can be summarised by two trite aphorisms. First, 'the regulator is regulated by the regulated firms.' That is, when the regulated firms are aware that the choices of the national regulator allow them to breach EC competition law, they should go back to the regulator and secure an alteration of the obligations imposed by the regulatory authority. Second, 'the Commission regulates the regulators.' In other words, the market failure which the national regulatory authority (NRA) causes by its intervention is cured by the application of EC competition law. In one sense, this second implication is desirable in light of the weakness of many NRAs, an issue we return to in part 2.3 below. On this ground, it may be argued that until national regulators can be trusted to act independently of the government and of the incumbent operator, the Commission's ability to use competition law to oversee the markets is necessary to ensure that markets are liberalised and incumbents are not protected by the regulators. However, this argument boils down to saying that the ends justify the means, and it is not surprising that Telefónica, like DT has decided to test the limits of the application of competition law. In its notice of appeal it complains of

the ultra vires acts of the Commission, which, in any event, infringe the principles of subsidiarity, proportionality, legal certainty, loyal cooperation and sound administration by intervening where the national telecommunications regulator had already acted, which was set up under European legislation and which acted in accordance with the powers and competences conferred on it by that legislation and under a set of rules based on the Community competition rules..$^{15}$

\footnotetext{
13 n 5 above at [164].

${ }^{14}$ Case T-5/02 Tetra Lavalv Commission [2002] ECR II-4381 at [157].

15 Action brought on 10 September 2007, Case T-336/07 Telefónica and Telefónica de España v Commission [2007] OJ C269/55.
} 
In light of the observations above, it is unlikely that these arguments will sway the CFI, but there should be some scope for limiting the application of competition law, not least when the national regulator is acting in a scheme set up by EC Law, as in the telecommunications sector.

\section{AMERICAN LESSONS?}

Some have suggested that in reconsidering the current law Europeans might learn from the Trinko judgment of the US Supreme Court. ${ }^{16}$ However the legal reasoning deployed by the Supreme Court is not directly comparable to that which the European courts could deploy. In Trinko, the court was confronted with a situation where the Federal Communications Commission and New York's Public Service Commission (the relevant telecoms regulators) had intervened under the Telecommunications Act 1996 to ensure the defendant complied with his access obligations, and the plaintiff was asking the courts to read established S.2 Sherman Act case law on refusals to deal more widely to embrace his claim. The US Statute in question explicitly provided that the antitrust laws could apply notwithstanding the regulatory scheme, so that for example had there been a cartel among regulated firms, the Department of Justice could have prosecuted this. ${ }^{17}$ However, the Supreme Court held that while the conventional antitrust rules applied, courts should be reluctant to develop the common law when this would encroach upon the sphere already covered by the Statute, most crucially because the Statute was designed to create a more competitive market. As Scalia J put it: 'the regime was an effective steward of the antitrust function."18 At first blush, this categorical assertion would seem to provide some support for the position taken by Telefónica in its appeal, however a closer look at the statutory framework suggests that Trinko is an unhelpful precedent. There are three points that distinguish Trinko and Deutsche Telekom: first, Trinko dealt with the overlap of two Federal Laws (not a state and a Federal Law, like in the European cases where the tension is between Article $82 \mathrm{EC}$ (primary law) and national law that implements secondary Community legislation; second the US Telecommunications Act made express provision for the parallel application of competition law; third Trinko merely held that the antitrust laws should not be extended to reach the facts at hand. The third point is significant because Telefónica and DT are not the first margin squeeze cases, although there were certain novel features in the detailed application of the law. Thus the Commission was not reading Article 82 more extensively to reach practices that are also regulated by national law. Therefore

\footnotetext{
16 Verizon Communications Inc v Law offices of Curtis Trinko 540 US 398 (2004). Notably D. Geradin 'Limiting the Scope of Article 82 EC: What the EU Can Learn from the US Supreme Court's Judgment in Trinko in the Wake of Microsoft, IMS, and Deutsche Telekom' (2004) 41 Common Market Law Review 1519. See for discussion G. Monti, EC Competition Law (Cambridge: Cambridge University Press, 2007) 472-4.

17 Section 601(b)(1) Telecommunications Act 1996 Act provides that 'nothing in this Act or the amendments made by this Act shall be construed to modify, impair, or supersede the applicability of any of the antitrust laws.'

18540 US 398, 413.
} 
the ratio decidendi in Trinko has nothing to teach the European courts, because had the same facts occurred in the US, the court would say that US antitrust applies, the matter would be uncontroversial. Moreover, Trinko has introduced a degree of uncertainty that compelled the Antitrust Modernization Commission to issue a clarification to explain that the Court only held that statutory duties to deal do not create a cause of action under the refusal to deal doctrine. ${ }^{19}$

One US doctrine that may be relevant in the Deutsche Telekom and Telefónica appeals is that of implied immunity. That is, when a statute is silent on the application or non application of antitrust laws, the courts will consider that the statute implicitly immunises the regulated parties from antitrust laws in scenarios where the statutory scheme is detailed and designed to deter and remedy anticompetitive harm, and where courts might feel hesitant at applying antitrust when it goes against the regulator's plans. ${ }^{20}$ The question arises whether this doctrine applies, for instance in the context of the Regulatory Framework in Electronic Communications. An answer that might be attempted is as follows: if a National Regulatory Authority (NRA) has acted to regulate a market, this means that the NRA has decided (with supervision from the Commission) that, among other things, the application of competition law is unlikely to be sufficient to remedy the anticipated anticompetitive practices. ${ }^{21}$ In these circumstances, it would seem that the NRA's choice to regulate should give the regulated party implied immunity from the application of EC competition law. By the same token, if an NRA does not act, then there is no implied immunity because the Directives seem to implicitly suggest that competition law applies. Accordingly the doctrine of implied immunity would require a more nuanced application than in the United States: in the US the doctrine immunises the application of antitrust always, in the EC, it may do so in cases of regulatory action but not in cases of inaction. However the doctrine of implied immunity has been developed in the context of Federal, not state, regulation; and so long as EC utilities regulation is national in character, then from a doctrinal perspective there is nothing to draw upon here. Nevertheless, both Scalia J's approach in Trinko and the implied immunity doctrine provide ammunition for suggesting that applying EC competition law without any regard to the regulatory framework is undesirable, and that good reasons should be provided for doing so, beyond the formalistic legal justifications offered so far.

The sole indisputably comparable doctrine from the United States that applies directly to the problem canvassed at the start of this essay is the 'state action

\footnotetext{
19 Antitrust Modernization Commission, Report and Recommendations 2 April 2007, Recommendation 67 (available at www.amc.gov).

20 The doctrine is discussed in United States v National Assn. of Securities Dealers, Inc., 422 U.S. 694 (1975); Gordon v New York Stock Exchange, Inc., 422 US 659 (1975); National Gerimedical Hospital and Gerontology Center v Blue Cross of Kansas City, 452 US 378 (1981) and Billing v Credit Suisse First Boston Ltd. (2007) US

21 Recital 27 of the Framework Directive [2002] OJ L180/33: 'It is essential that ex ante regulatory obligations should only be imposed where there is not effective competition... and where national and Community competition law remedies are not sufficient to address the problem...'.
} 
doctrine' developed by the Supreme Court whereby the Sherman Act does not pre-empt state regulation, ${ }^{22}$ nor does it pre-empt regulation by non-state bodies (e.g. regulators) when this anticompetitive regulation is clearly articulated as state policy (that is the state has clearly decided that a policy objective trumps competition) and the state actively supervises the implementation of that policy so as to avoid regulatory capture. ${ }^{23}$ The question arises whether the EC's own state action doctrine (recently considered in the Mauri and Cipolla cases for example) should be widened to encompass the application of sector specific regulation when this has anticompetitive effects. ${ }^{24}$ However, an objection to this line of inquiry would be that there is little to be gained from a weak doctrine: the American Bar Association, the Federal Trade Commission and the Antitrust Modernization Commission have all expressed concerns that the lower courts have read this doctrine too extensively at the expense of effective competition. ${ }^{25} \mathrm{~A}$ second objection is that comparison and lesson drawing is dangerous given the different constitutional makeup of the US and EC. State-sovereignty seems to provide a good reason for the greater willingness of the Americans to tolerate anticompetitive state laws, while the supremacy of EC Law seems to pull in the opposite direction. ${ }^{26}$

\section{Policy CONSIDERATIONS}

So far I have considered the legal arguments surrounding the concurrent application of competition law and sector specific regulation, however beneath these lie two policy considerations that help frame the debate in a wider context: the role of sector specific regulation in recently liberalised utilities, and the institutional makeup of regulators in the Member States.

As regards the role of regulation, a significant corollary of the Commission's views about the primacy of EC competition law over national law is that EC Directives that liberalise utilities strive to avoid requiring Member States to implement a scheme of regulation that places competition second. That is, the directives do not as a rule require Member States to put into place a regulatory structure that privileges say the protection of the environment or of consumers over competition. All policy goals should be achieved within the framework of competitive markets. Even the provision of universal services is increasingly to be achieved through competitive markets rather than through restrictions of

22 Parker v Brown, 317 U.S. 341 (1943).

23 California Retail Liquor Dealers Ass'n v Midcal Aluminum, Inc., 445 U.S. 97 (1980); FTC v Ticor Title Insurance Co., 504 U.S. 621 (1992).

24 Case C-250/03 Mauri [2005] ECR I-1267; Joined Cases C-94/04 and C-202/04 Cipolla and Others judgment of 5 December 2006.

25 Antitrust Modernization Commission n 19 above, 343, citing the earlier reports of the FTC and ABA.

26 E. Fox 'State Action in Comparative Context: What if Parker v Brown were Italian?' (2003) Fordham

Corporate Law Institute (Hawk ed. 2004). 
competition. ${ }^{27}$ This policy position draws support from Article 4(1) EC which requires that the Community's economic policy is 'conducted in accordance with the principle of an open market economy with free competition.' Therefore EC Competition Law is also of a higher order to other Community policies, and Directives under Articles 86(3) and 95 can be challenged if they are anticompetitive. Perhaps it is this legal conclusion that so irked President Sarkozy and led him to ask for a modification of the Treaty in an attempt to tone down the supremacy of competition law. Article 2(3) of the Treaty on European Union, as amended by the Lisbon Treaty provides as follows:

The Union shall establish an internal market. It shall work for the sustainable development of Europe based on balanced economic growth and price stability, a highly competitive social market economy, aiming at full employment and social progress, and a high level of protection and improvement of the quality of the environment. ${ }^{28}$

In contrast, the Treaty establishing a Constitution for Europe had set out as one of the Union's objectives 'an internal market where competition is free and undistorted', ${ }^{29}$ language reflecting the current Article 4 EC. It remains to be seen whether the deletion of competition from this provision is sufficiently significant to modify the current legal position, and whether the EU legislature will now consider tempering the insistence on competition in Article 95 Directives. Admittedly this is what the French president intended, in particular in the face of continuing challenges against France's energy policy. ${ }^{30}$ This policy debate about how far competition should be the guiding principle raises the question of whether there are circumstances where the non-application of competition law may be justified when a national regulator chooses to tolerate an anticompetitive solution as a means of achieving other policy objectives.

A second policy implication that may be utilised in particular to justify the Commission's position in Deutsche Telekom case is the weakness of the German regulator. For instance it has been noted that the regulator (RegTP) is subject to

\footnotetext{
27 See for example Proposal for a directive of the European Parliament and of the Council amending Directive 97/67/EC concerning the full accomplishment of the internal market of community postal services COM (2006) 594 final which proposed removing the reserved sector altogether, thus abandoning the approach whereby the supply of universal services is financed by monopoly profits.

${ }^{28}$ Treaty of Lisbon amending the Treaty on European Union and the Treaty establishing the European Community (3 December 2007). Available at http://www.consilium.europa.eu/cms3_fo/ showPage.asp?id=1297\&lang=en). However, this is qualified by the protocol on the internal market and competition by which the high contracting parties, considering that the internal market as set out in Article 2 of the Treaty on European Union includes a system ensuring that competition is not distorted, have agreed that: to this end, the Union shall, if necessary, take action under the provisions of the Treaties, including under Article 308 of the Treaty on the Functioning of the European Union.' This retains the Community's competence to legislate to further competition in the internal market (Article 308 was used for instance as a legal basis for the EC Merger Regulation).

${ }^{29}$ Article I-3(2), (2004) Cm 6429.

${ }^{30}$ See the GDF and Suez merger that has been agreed recently (Financial Times 4 September 2007).
} 
political interference which undermines its independence. ${ }^{31}$ Similar influence from government can be detected in the workings of the Spanish regulator. ${ }^{32}$ And the Commission has also noted that other regulators in the field of electronic communications are insufficiently independent. ${ }^{33}$ Therefore, a 'regulator of regulators' may be necessary as Member States make the transition from state regulation of network industries to independent regulatory agencies. However this argument is really a reflection of the failure of EC Regulation, not of the legitimacy of the concurrent application of EC competition law. The 2002 Regulatory Framework already gives the Commission significant latitude to regulate the regulators; the fact that even more powers are needed to admonish national regulators suggests a somewhat imperfect legislative scheme.

However, one can turn this line of argument on its head and suggest that the reason why the current regulatory scheme leaves space for national variation is precisely because at this stage in the political process Member States have not yet agreed to relinquish political control over utilities regulation. And on this line of argument, the Commission's choice to apply competition law when it disagrees with the regulator's position undermines the choice of the EU legislature to limit the reach of sector specific regulation so as to afford Member States some latitude in their policy choices. One powerful objection to this line of defence however is that regulation which is so dependent on government discretion is highly inimical to the promotion of legal certainty for market players and as a result undermines incentives by existing players and new entrants to invest in these markets. Accordingly, even if one were to agree that the pursuit of goals other than competition is legitimate, a highly discretionary regulatory scheme is counterproductive. This explains why the Commission's current proposals to reform the directives on telecommunications, electricity and postal services seek to insulate national regulators from government. In telecommunications for example, the proposals to reform the Framework Directive require that Member States 'ensure that national regulatory authorities exercise their powers independently, impartially and transparently', that regulators do not take instructions from other bodies, that appeals from their decisions are to a national court, that the head of the national regulatory authority cannot be dismissed unless guilty of serious misconduct or she no longer fulfils the criteria for appointment published in advance by the Member State, and that national regulatory authorities have adequate financial and human resources to carry out the tasks assigned to them and that they have separate annual budgets. 34 A similar line is adopted in the

\footnotetext{
31 K. Stockmann 'Comment' in H. Ullrich (ed.) The Evolution of European Competition Law (Cheltenham: Edward Elgar, 2006).

32 J. Jordana and D. Sancho 'Policy networks and market opening: Telecommunications liberalization in Spain' (2005) 44 European Journal of Political Research 519.

33 E.g. V. Reding 'Why we need more consistency in the application of EU telecom rules' SPEECH/06/795, 11 December 2006.

34 Article 3(3) Proposal for a directive of the European Parliament and Council amending Directives 2002/21/EC on a common regulatory framework for electronic communications networks and services, $2002 / 19 / \mathrm{EC}$ on access to, and interconnection of, electronic communications networks and services, and
} 
electricity sector, the draft directive on common rules for the internal market in electricity requires that Member States guarantee the independence of the regulatory authorities and that it exercises its powers impartially and transparently. Like in telecommunications, the regulatory authority is independent of government, it has budgetary autonomy and adequate resources to carry out its tasks. ${ }^{35}$ Accordingly, once national regulatory authorities are designed in a way that avoids government interference, then the application of competition law in situations where it risks undermining the policy choices of the regulator may be unjustified, but until that moment arrives, competition law serves as a safeguard against political meddling.

Therefore, from a policy perspective, the need for institutional reform serves as a justification for the status quo: competition law applies even when it contradicts national regulatory policy in order to correct the weakness of national regulators today. But this is a temporary solution pending adequate reform of national regulatory authorities. Once these reforms are in place, then the application of competition law can be more sensitive to the policy choices of the independent regulator.

\title{
QUESTIONING THE SUPREMACY OF COMPETITION LAW BY REFERENCE TO UTILITIES POLICY
}

\begin{abstract}
Above I canvassed the view that decisions like Deutsche Telekom and Telefónica are justified in the current climate, characterised by politically dependent national regulators, and that the approach taken in those decisions should be reconsidered once national regulators can be trusted to act in the interest of the industry. In this section, I consider whether competition law should not be more deferential to regulators today, by considering examples of what can be described as legitimate attempts to regulate utilities in the public interest.
\end{abstract}

\section{COMPETITION VERSUS INNOVATION}

A traditionally difficult issue in competition law enforcement is managing the promotion of allocative and dynamic efficiency. While in certain situations ensuring the former serves to guarantee the latter, there are also scenarios where trade-offs may have to be made whereby one sacrifices allocative efficiency in favour of dynamic efficiencies. Antitrust law has long struggled with applying a trade-off when regulating firms with market power, good examples of this can be seen in the debates over the application of the efficiency defence in merger

2002/20/EC on the authorisation of electronic communications networks and services COM(2007) 697 final.

35 Article 22a Proposal for a Directive of the European Parliament and of the Council amending Directive 2003/54/EC concerning common rules for the internal market in electricity COM (2007) 528. 
regimes, ${ }^{36}$ and the debates about the refusals by dominant firms to licence intellectual property rights, most recently discussed in the Microsoft judgment. ${ }^{37}$

A similar tension may be observed in the several policy objectives set out in the Framework Directive for electronic communications, which requires national regulatory authorities to promote competition by ensuring that users 'derive maximum benefit in terms of choice, price and quality' while also 'encouraging efficient investment in infrastructure and promoting innovation. 38 As Professor Larouche notes these two goals are not necessarily complementary and he considers it unusual that there is no more concrete steer towards investment and innovation in light of the Lisbon agenda which is designed to increase investment and improve the competitiveness of European industry. ${ }^{39}$

An example of a mechanism that could be used by a regulator to prioritise dynamic over allocative efficiency is a 'regulatory holiday' that suspends regulatory obligations when a regulated firm develops a new product. The idea behind a regulatory holiday is akin to granting an IP right: the holder is free from competition for a particular time period, and the prospects of this holiday are an incentive to innovate. In contrast the Commission thinks that competitive markets are the best way to encourage investment and is against regulatory holidays. An example suggested by Alexandre de Streel helps us see the conflict, it concerns the roll out of VDSL lines in Germany. ${ }^{40}$ Initially the German regulator took the view that VDSL lines were not in the same market as ADSL lines, so there was no need to regulate broadband access obtained through VDSL. (In effect this seems to be a strategic market definition designed to avoid imposing regulations based on the Access Directive.) However the Commission objected to this market definition, taking the view that ADSL and VDSL lines formed part of the same market in that the services that could be channelled through these networks are the same, and urged the German regulator to ensure that there is broadband access to VDSL. In particular the Commission noted that Deutsche Telekom had begun a programme of rolling out VDSL lines and foresaw the risk of foreclosure for competitors if this market went unregulated. ${ }^{41}$ This position is now replicated in the European Regulators' Group Revised Common Position on Remedies. ${ }^{42}$ The ERG argues that rather than offering a regulatory holiday to the

\footnotetext{
36 See generally G. Monti 'Merger Defences' in Amato and Ehlermann n 8 above.

37 Case T-201/04 Microsoft v Commission judgment of 17 September 2007 at [688-712]. And see generally D. Kanter 'IP and compulsory licensing on both sides of the Atlantic - an appropriate antitrust remedy or a cutback on innovation?' (2006) 27 European Competition Law Review 351; L. Ritter 'Refusals to Deal and Essential Facilities: Does Intellectual Property Require Special Deference Compared to Tangible Property?'(2005) 28(3) World Competition 281

38 Article 8(2)(a) and (c) Directive 2002/21 Framework Directive [2002] OJ L108/33.

39 P. Larouche 'What went wrong: the European perspective' TILEC Discussion Paper DP (2003-001) 14-15.

40 A. de Streel 'The Scope of Economic Sector Regulation in Electronic Communications' (2006) 62 Communications \& Strategies 147, 162.

41 Case DE/2005/262 - Wholesale Broadband Access in Germany: Withdrawal of Serious Doubts (23 December 2005).

42 Revised ERG Common Position on the approach to Appropriate remedies in the ECNS regulatory framework ERG 06(33), 116-118 available at: http://erg.eu.int/documents/index_en.htm.
} 
innovator, the access remedy should be designed to reward his investment, so for example the price of access can be higher when one seeks access to VDSL. Two comments are warranted: the first is that the ERG seems to think that it is able to calculate exactly what sort of compensation the innovator should get so that the incentive to innovate is not dented. This seems somewhat optimistic. ${ }^{43}$ But besides that practical point I think the ERG position is underpinned by a familiar ideology. Consider this passage:

It is undoubtedly the case that the investors require a reasonable opportunity to make a fair return on their investments, which properly reflects the risks undertaken. However, a guaranteed monopoly over access is by no means a pre-requisite for such a return. ${ }^{44}$

The innovator is only entitled to a 'fair return' on his investment. Fair according to whose criteria? Fair according to the innovator means 'as much as possible', but fair for the ERG seems to suggest more limited income. More specifically, an inventor will normally have a set of projects on the run, only one of which may be successful - is the reward limited to the costs of developing the one successful product? Surely the inventor needs to recoup all costs sunk in developing new products. Limiting revenue streams dents incentives to innovate. Moreover, the passage quoted above has resonance with the EC's approach in Article 82: that dominant firms have 'special responsibilities' and that excessive pricing is a possible abuse. Compare with the US instead where the successful competitor must not be turned upon when he wins and excessive pricing is not punished by s.2 Sherman Act (the two are intimately related as high prices are the reward for success and also invite entry). The American approach is premised on the belief that false positives are risky and that it is best to allow potentially harmful behaviour than to dent incentives to innovate. There are therefore two competing paradigms for the promotion of innovation, one which tolerates the risks of monopoly and one which does not. In view of the fact that innovation in the EU is low compared to the US, and in light of the Lisbon agenda, might a more lenient position on regulatory holidays be warranted? Or at the very least, might national regulators be given the flexibility to experiment with regulatory holidays? In defence of the Commission's concerns over regulatory holidays, one should note that these would tend to be granted to the incumbent - that is a telecommunications operator that has historically benefited from exclusive rights and state support. In this view, regulatory holidays are a retrograde step when the key policy consideration is increasing competition through asymmetric regulation targeting former state monopolies.

\footnotetext{
43 On the other hand, a comparable exercise is practised in deciding whether restrictions of competition are indispensable in Article 81(3) proceedings. See Guidelines on the application of Article 81(3) of the Treaty [2004] OJ C101/97] at [80].

44 ibid, 118.
} 
A more general argument against regulatory holidays is that they lead to different regulation across the Member States, thereby harming firms that wish to invest in more than one Member State. The argument goes that if one wishes to promote pan-European telecommunications services, one should strive for regulatory uniformity. ${ }^{45}$ The argument was accepted by the Commission whose reform of the Framework Directive is designed to grant it veto powers over the remedy prescribed by national regulators, which means that every step of a national regulator's tasks would be subject to Commission approval. ${ }^{46}$ While uniformity and legal certainty are undoubtedly important to secure investment, it may also be argued that a rigid regulatory framework is less likely to discover the best way to regulate markets than a scheme which allows different regulatory authorities to experiment with divergent forms of regulation. This suggestion has been made by Larouche and de Visser who consider the possible risk of all telecommunications regulators making the same (wrong) decision and contrast this scenario with one of 'regulatory emulation' a process whereby regulators experiment with different models, and through an iterative process the best way of regulating markets is discovered. In contrast, the authors note that at present there is little attempt by regulators to experiment with innovative regulatory tools, instead usually one of the regulators from the larger Member States takes the lead and the rest follow. ${ }^{47} \mathrm{~A}$ balanced approach that favours uniform regulation when there is consensus but also tolerates regulatory experiments when it is not clear how to best regulate markets may be a workable means to determine how to regulate markets in the long term. But for this to work the regulated need to be certain that they will be free from liability under competition law.

If we turn our attention to energy policy, we see that there are instances where the Commission is prepared to trade-off dynamic and allocative efficiency when granting exemptions from third party access to undertakings that develop new interconnection capacity. ${ }^{48} \mathrm{New}$ capacity is necessary to help develop the internal market and break down national monopolies by creating an EU-wide wholesale market. Article 7 of the Electricity Regulation sets out six conditions that must be met before an exemption is granted, and establishes a procedure whereby the parties seeking exemption first notify the relevant NRA, followed by consultation with other government bodies, and the decision to exempt must be notified to the Commission that has the power to veto the grant of an exemption. ${ }^{49}$ The effect of an exemption is that the firms building the interconnector can then buy electricity cheaply from one end and sell it at the

\footnotetext{
${ }^{45}$ I am grateful to Andy Tarrant for this observation. See BT The Economic Benefits from Providing Businesses with Competitive Electronic Communications Services - Overview Report (5 June 2007) available at www.btplc.com. ${ }^{46}$ Proposal, n 34 above, Article 7(4).

47 P. Larouche and M. de Visser "The Triangular Relationship between the Commission, NRAs and National Courts Revisited' (2006) 64 Communications \& Strategies 125, 133-135.

48 See P.D. Cameron, Competition in Energy Markets (Oxford: Oxford University Press, 2nd ed, 2007) at [5.95-5.105].

${ }^{49}$ Article 7 Regulation 1228/2003 on conditions for access to the network for cross-border exchanges in electricity [2003] OJ L176/1.
} 
other end where demand is less elastic. These financial rewards pay for the risk involved in building the new interconnector. As Kim Talus concludes, the rationale is to favour long-term efficiency gains over short-term advantages. ${ }^{50} \mathrm{~A}$ similar scheme operates in the gas market for major investments where third party access obligations are suspended; 51 and national regulators here have also provided other national schemes to create incentives to invest in gas infrastructure..$^{52}$ Judged numerically the exemption in the gas sector has been utilised significantly more frequently than in the electricity sector, where only one exemption has been granted and another application is pending. ${ }^{33}$ These provisions resemble the notification/exemption procedures in Regulation 17/62 and operate in a way similar to Article 81(3) EC.

There are three aspects that distinguish the energy example from the regulatory holiday in the telecoms sector: procedurally, the Commission is heavily involved in the grant of an exemption, substantively the degree of market power that the investors secure is not as significant, and economically the exemption is given when new infrastructure is built while in the electronic communications the reluctance to afford regulatory holidays applies to upgrades to existing infrastructure. Nevertheless in both instances the benefit to the Community is comparable: new facilities are introduced that help strengthen Europe's economy, at the expense of allocative efficiency in the short run.

Now, let us assume that an NRA chooses to award a regulatory holiday to a telecoms firm in spite of Commission attempts to thwart that policy choice. Can Article 82 apply if this holiday allows the firm to abuse its dominant position? As we saw above the answer is in the affirmative because the supremacy of Community law pre-empts any inconsistent judgment call by the regulator - even if the regulator thought there were good economic reasons for favouring dynamic efficiency. What if an NRA grants an exemption in for an electricity interconnector and the Commission does not veto it? Does this immunise the behaviour of the undertakings? The answer should be in the negative because the exemption only excuses the undertaking from the obligations in the energy legislation, it does not create a general derogation from other Treaty obligations. The scenario is analogous to one where an agreement benefits from a Block Exemption may still be subject to challenge under Article 82. So as a matter of law it seems that even a Commission-sanctioned regulatory holiday would remain subject to competition law. However, in practice one might argue that since the criteria to be taken into consideration when granting the exemption in the electricity market include those in Article 81(3), then it would be very odd for a

\footnotetext{
${ }^{50}$ K. Talus 'Monopolies in EC Energy Law - Interconnectors' (2004/2005) 14 Utilities Law Review 256, 258.

51 Article 22 Directive 2003/55 concerning common rules for the internal market in natural gas [2003] OJ L 176/57. For Discussion see DG Competition Report on Energy Sector Inquiry SEC(2006)1724 at [236-242].

${ }^{52}$ Council of European Energy Regulators Investment in Gas Infrastructure and role of EU National Regulatory Authorities - 12 May 2005.

${ }^{53}$ DG Competition report on energy sector inquiry SEC(2006)1724 at [346].
} 
competition law claim to succeed. ${ }^{54}$ Nevertheless, a person dissatisfied with the exemption seems to be free to choose between appealing the exemption and challenging the undertakings using competition law. In this scenario it would seem that the court should develop a doctrine akin to the 'implied immunity' standard used in the US courts to prevent antitrust law from frustrating the regulator's legitimate choice. ${ }^{55}$ Or at the very least, satisfying the requirements of the Regulation could be said to create a rebuttable presumption of legality under EC competition law.

\section{ENERGY POLICY: SECURITY VERSUS COMPETITION}

Energy policy is not merely about creating a competitive market; there are noneconomic considerations as well. In the final report on the energy sector inquiry the Commission states that European energy policy is directed at achieving the three closely related objectives of: a competitive and efficient energy sector, security of supply and sustainability. ${ }^{56}$ Above, I suggested that an efficient market might require a temporary restriction of competition. Here I consider whether restrictions of competition should be tolerated if forbearance helps pursue the other goals of energy policy. Two examples serve to suggest that tradeoffs between competition and security of supply are already made at Community and at national level.

Looking to the Commission's policy, an interesting analysis by Kim Talus has suggested that the regulation of long-term gas supply contracts might be affected by political considerations. ${ }^{57}$ Long-term contracts (lasting 15-20 years) between gas producers and the national incumbent foreclose entry by making it difficult for new entrants (who buy gas upstream and resell in downstream markets) to bid for the gas supplies on a regular basis and to compete against the incumbent supplier. ${ }^{58}$ Accordingly strict scrutiny seems warranted. The EU imports a considerable amount of gas, in particular from Norway, Russia and Algeria, ${ }^{59}$ and

\footnotetext{
${ }^{54}$ Even under Article 82, it may be argued that behaviour that fulfils the four conditions in Article 81(3) may be objectively justified for the purposes of Article 82 .

55 H. Hovenkamp 'Antitrust and the Regulatory Enterprise' (2004) Columbia Business Law Review 335, 345-6.

${ }^{56}$ Communication from the Commission - Inquiry pursuant to Article 17 of Regulation (EC) No 1/2003 into the European gas and electricity sectors (Final Report) COM (2006) 851 final paragraph 6; Communication from the Commission to the European Council and the European Parliament - An energy policy for Europe $\operatorname{COM}(2007) 1$ final, paragraph 1 indicates three goals: sustainability, security of supply and competitiveness (query whether competition and competitiveness are synonyms). In France, energy policy has four objectives: energy independence and the security of supply; protection of the environment; energy at low cost for households and industries; social and territorial cohesion (S. Meritet 'French perspectives in the emerging European Union energy policy' (2007) 35 Energy Policy 4767).

${ }^{57}$ K. Talus 'Long-term gas agreements and security of supply - between law and politics' (2007) 32 European Law Review 535.

${ }^{58}$ DG Competition report on energy sector inquiry SEC(2006)1724 at [121] and [123].

$59 \mathrm{ibid}$, at [189], noting that gas finds in the EU are unlikely so that dependence on imports will increase. See also House of Lords European Union Committee The Commission's Green Paper, "A European Strategy for Sustainable, Competitive and Secure Energy" 41st Report of Session 2005-06 HL Paper 224 at [15] noting that Russia is the largest European gas supplier.
} 
Talus notes that the duration of long term contracts that the Russian supplier, Gazprom, has in place with EU customers is longer than that normally allowed in intra-Community trade and suspects that this increased leniency has more to do with a political interest in keeping the Russian supplier happy than in rewarding it for past or anticipated investment. This is not the first instance that Article 81 has been applied (or not applied) in a manner that is designed to achieve other policy goals. ${ }^{60}$

Turning to the national level, the regulation of the E.ON/Ruhrgas merger offers a provocative case study. The firms announced a merger in 2001. E.ON (with RWE) held a joint dominant position in the electricity market, and Ruhrgas is the dominant gas supplier in Germany. The German Bundeskartellamt prohibited the move, but it was cleared by the German government under a special procedure in the German antitrust laws that allow the government to authorize ostensibly anticompetitive behaviour if 'the restraint of competition is outweighed by advantages to the economy as a whole following from the concentration, or if the concentration is justified by an overriding public interest.' ${ }^{61}$ Among the reasons offered by the German government (against the advice of the majority of the German Monopolies Commission) was that the merger would ensure security of supply in the gas market, particularly important because Germany depended on gas imports and the government considered that the merger would help ensure secure supplies of Russian gas. The merger was cleared on the condition that the firms work towards achieving security of supply. While many economists criticised this as an anticompetitive result designed to create a national champion and as frustrating the objectives of liberalisation, ${ }^{62}$ Professor Helm opined that this merger clearance could be read as a regulatory bargain whereby the firms gain market power and in return must invest in ensuring security of supply. ${ }^{63}$ This view is not wholly unreasonable given that most energy generation plants in Germany need replacing and that incentives to invest should be created. ${ }^{64}$ Perhaps unsurprisingly E.ON Ruhrgas has recently issued a press release to indicate how it is investing in security of supply measures to comply with the political demands placed upon it at the time the merger was cleared. It mentioned the expenditure of $€ 4.7$ billion on 'new transmission lines and gas storage facilities in the E.ON markets, the development of transmission infrastructure to Europe, new supply projects and involvement in gas production.' Moreover, the Chairman referred to plans for a terminal for liquefied natural gas in Wilhelmshaven and the Nord Stream pipeline through the Baltic: 'Nord Stream is a project having a European dimension. Gas from this pipeline is intended for

\footnotetext{
${ }^{60}$ See generally G. Monti 'Article 81 EC and Public Policy' (2002) 39 Common Market Law Review 1057. ${ }^{61}$ Act Against Restraints of Competition, s 42.

62 e.g. E. Lieb-Dóczy 'The E.ON Ruhrgas Merger: The German Government Decides Against Competition' NERA Energy Regulation Brief 14 (August 2002).

${ }^{63}$ D. Helm ‘The Assessment: The New Energy Paradigm' (2005) 21 Oxford Review of Economic Policy 1,11 .

${ }_{64}$ G. Brunekreeft and D. Bauknecht 'Energy Policy and Investment in the German Power Market' TILEC Discussion Paper DP 2005-031 (October 2005) 34-35.
} 
the entire EU. The project is being executed by using state-of-the-art technology and applying the highest environmental standards. ${ }^{65}$ Likewise other commentators have noted that E.ON has invested in Italy, thus injecting competition in that national market as well. ${ }^{66}$

Granted, some will argue that security of supply is best achieved by an integrated market, however this argument is unconvincing given that the sources of energy are located outside the EU, so while an internal market can solve some security issues, it can do less towards ensuring adequate supplies of gas. Moreover, when faced with a fairly concentrated supply side of gas production, it may well be that a comparably strong set of buyers are better able to guarantee security of supply than a more workably competitive market. ${ }^{67}$ Whatever the substantive merits of the German government's decision (and in this paper I take no view as to whether the decision was right) the general point that arises from this discussion is that competition and security of supply may not always be achieved by always prioritising competition law. Even the House of Lords European Union Committee, whose views on the Community's energy policy favour a market-oriented policy recognised that some compromise between the three objectives are necessary an that the cost of energy may have to rise in order to ensure security of supply and reduced carbon emissions. ${ }^{68}$

The question of how to guarantee energy security is laden with uncertainty, in particular given the role of Russian gas supplies in the EC. ${ }^{69}$ It is likely that a variety of policy responses are required, from liberalising markets to providing subsidies for the production of energy in different ways. Among the many policy options, it may be that occasionally suspending the application of competition law might be necessary to achieve energy security too. My criticism of the current legal position is that this policy option is not tolerated: EC competition law takes precedence as a rule (except when, tacitly, as Talus notes anticompetitive agreements are tolerated), without the possibility of debating whether, in given instances, less competition might lead to more energy security.

\footnotetext{
65 Press release 23.5.07 available at: http://news.eon-ruhrgas.com/ArtikelDetail.aspx?KategorieID= $3 \&$ ArtikelID $=14679 \&$ Kultur $=$ en

66 A.J. Padilla et al. 'The Proposed Acquisition of Endesa by Gas Natural' [2004/2005] 14 Utilities Law Review 268, 269.

${ }^{67}$ This is the view put forward by the incumbents in the energy report (n 57 above, at [626]).

68 The Commission's Green Paper, "A European Strategy for Sustainable, Competitive and Secure Energy" 41st Report of Session 2005-06 HL Paper 224, at [55] and [57].

${ }^{69}$ For an interesting overview see D. Finon and C. Locatelli 'Russian and European gas interdependence: Could contractual trade channel geopolitics?' (2008) 36(1) Energy Policy 423.
} 


\section{QUESTIONING THE VALUE AND LEGITIMACY OF REGULATORY ANTITRUST}

In part three I suggested there may be good reasons for not allowing antitrust to interfere with policy choices of the regulator. In contrast, the current policy seems to be the obverse: regulation is carefully circumscribed with the aim that it should recede,$^{70}$ while antitrust is allowed to grow. In this part I offer a critique of the growth of antitrust law, in particular drawing upon the Commission's justification (articulated in its response to the Telefónica case quoted in the introduction), that sector specific regulation is an ex ante means of regulating markets, while competition law is an ex post mechanism for regulating markets. This point is made regularly by the Commission and some of its implications are elaborated upon in the Guidelines on market analysis and the assessment of significant market power. Here the Commission notes that parallel proceedings under SSR and EC competition law are possible but that these would address different kinds of problems. ${ }^{71}$ However elegant this distinction is in theory, it has been noted that remedies in merger cases, under Article 81(3), and in settled cases can be labelled as ex ante interventions. ${ }^{72}$ It is even arguable that Article 82 is often applied $e x$ ante; in France $v$ Commission for example, the CFI reaffirmed that a finding of predatory pricing does not require proof that the predator is likely to recoup his losses (arguably a necessary step for predation to be economically rational), nor that predatory pricing is likely to exclude rivals, once it is shown that the practice has an anticompetitive object. ${ }^{73}$ And in Microsoft $v$ Commission the CFI explained clearly the rationale behind not requiring the Commission to show that exclusionary abuses have exclusion as their likely effect:

Article 82 EC does not apply only from the time when there is no more, or practically no more, competition on the market. If the Commission were required to wait until competitors were eliminated from the market, or until their elimination was sufficiently imminent, before being able to take action under Article $82 \mathrm{EC}$, that would clearly run counter to the objective of that provision, which is to maintain undistorted competition in the common market and, in particular, to safeguard the competition that still exists on the relevant market. ${ }^{74}$

\footnotetext{
${ }^{70}$ M. Monti, Competition and Regulation in the new Framework, Speech of 15.7.2003; E. Liikanen, Accelerating Broadband in Europe, Speech of 28.1.2003: 'Competing network infrastructures are essential for achieving sustainable competition in network and services in the long term. When facilities-based competition is effective, the new framework will require ex-ante obligations to be lifted. Investment in new and competing infrastructure will bring forward the day when these obligations can be relaxed.'

71 [2002] OJ C165/6 at [31]

72 See P. Larouche, Competition Law and Regulation in European Telecommunications (Oxford: Hart, 2003) ch.3.

${ }^{73}$ Case T-340/03 France Telecom SAv Commission (judgment of 30 January 2007) at [196].

${ }^{74}$ Case T-201/04 Microsoft v Commission (judgment of 17 September 2007) at [561].
} 
The difficulty with the CFI's attitude in both of these cases is that the Commission is relieved of even the burden of showing that the practices are likely to have exclusionary effects merely because there is evidence that the practices have an anticompetitive object. This reads across from Article 81(1) which distinguishes between agreements anticompetitive by object and effect and turns Article 82 into an $e x$ ante provision.

The key problem of ex ante competition law that I wish to emphasis here is that, as others have noted, competition law has been applied, ex ante, in a regulatory fashion..$^{75}$ One example from the utilities sector can be mentioned to give a flavour of the nature of 'regulatory antitrust'. This is the settlement that the EC Commission reached with Gazprom and ENI in October 2003 concerning the supply of natural gas from Russia into the EC. ${ }^{76}$ The agreement contained a clause preventing ENI from exporting gas it purchased from Gazprom, and a clause that required Gazprom to seek ENI's approval for any sales to other wholesalers in Italy. The settlement went beyond the two parties deleting these offending contractual clauses (both patently in breach of Article 81 EC), in addition ENI undertook (1) to offer significant gas volumes to customers located outside Italy over a period of five years, a measure designed in particular to help increase competition in the Austrian and German markets; and (2) to increase the capacity of is TAG pipeline which runs through Austria and carries Russian gas into Italy, and to promote improved third party access to this pipeline. The concern of antitrust purists in these two limbs of the settlement is that they are not closely related to the infringement that triggered the investigation, and that the Commission is using competition law settlements to resolve a series of structural issues designed to create competitive markets. The concerns over this approach are confirmed when hearing the opinion of the then Commissioner for competition. In his view, the decision

goes to show that during the initial delicate transition phase from monopolised to liberalised energy markets, the focus should lie, in some occasions, on Commission's interventions improving effectively the market structure, rather than on formal procedures imposing fines. [...] I consider this settlement to be a major breakthrough for the creation of a gas market in the European Union. ${ }^{77}$

\footnotetext{
${ }^{75}$ E.g. M. Cave and P. Crowther 'Co-ordinating regulation and competition law - ex ante and ex post' in Swedish Competition Authority The Pros and Cons of Antitrust in Deregulated Markets (2004); G. Monti, n 16 above, 474-485; A. Christiansen 'Regulation and EU Merger Control in the liberalised energy sector (http://ssrn.com/author=369349).

${ }^{76}$ Commission reaches breakthrough with Gazprom and ENI on territorial restriction clauses 6 October 2003 (IP/03/1345).

77 M. Monti 'Applying EU Competition Law to the newly liberalised energy markets' Speech at the World Forum on Energy Regulation Rome, 6 October 2003. (available at: http://ec.europa.eu/comm/ competition/speeches/).
} 
These sound like the words of an industry regulator, not those of an antitrust authority. The policy justification for this aggressive approach is clear: as Member States continue to dither and prevaricate over energy liberalisation, the Commission uses alternative techniques to create competitive markets and to cajole Member States to agree to further liberalisation.

Some have questioned the legitimacy of this approach, ${ }^{78}$ while others have taken this as a natural evolution of a maturing system of competition law. ${ }^{79}$ One remarkable feature of this approach is that in stark contrast to the limitations imposed on telecommunications regulators, few limits apply to fetter the discretion of the competition authority: it may choose to act when in the Community interest, ${ }^{80}$ and in reaching settlements with undertakings it does not even bear the burden to prove the infringement, only to raise enough evidence to issue a statement of objections and this brings the party to the negotiating table, offering what remedy the Commission wishes - and as the Gasprom/ENI settlement shows, these remedies can go well beyond those necessary to solve the competition problems. These decisions have been analysed from a number of perspectives. Political scientists for example have noted how certain decisions in the telecommunications sector in the late 1980s were useful in creating incentives for Member States that were reluctant to liberalise the sector to participate in the legislative process, a process which they note was less successful in the energy markets because the Commission lost some test cases in the late 1990s. ${ }^{81}$ From a legal/economic perspective Cave and Crowther raise three issues: first whether negotiated settlements risk a sub-optimal result given that the firms are unlikely to wish to cooperate fully. In response it can be argued that the Commission has strong powers against non-cooperation: fines may be imposed if the parties do not abide by the terms of a commitment decision and if there is non-compliance with commitments in merger cases a fine or dissolution of the merger are possible remedies. ${ }^{82}$ Second, they question whether the application of competition law may lead to sub-optimal outcomes, perhaps especially because in contrast to a sectorspecific regulator the competition authority lacks expertise, but they conclude (with little analysis) that '[i]n energy, where the political process for passing adequate sector-specific legislation at the EU level has been far more intractable, the benefits of a ex ante intervention under competition law seem clearer. ${ }^{93}$ It is submitted that this conclusion is intuitively appealing but cannot be supported without more evidence.

Third, and most significantly for the purposes of this paper, they question whether regulatory antitrust may be disproportionate. This question can be answered by considering the occasional signals from the legislature and the Courts

\footnotetext{
78 P. Larouche, Competition Law and Regulation in European Telecommunications (Oxford: Hart, 2000) 112-127.

${ }^{79}$ D. Goyder, EC Competition Law (Oxford: Oxford University Press, 4th ed, 2003) 529-30.

${ }^{80}$ Case T-24/90 Automec II [1992] ECR II-2223.

${ }^{81}$ For an overview M. Cini and L. McGowan, Competition Policy in the European Union (London: Macmillan, 1998) ch.9.

82 Article 14(2)(b) ECMR (fines); Article 8(4) ECMR (de-merger).

${ }^{83}$ Cave and Crowther $\mathrm{n} 75$ above 28.
} 
that the concept of proportionality may serve to delimit the scope of the Commission's interventionism. First, while the Commission may impose structural remedies for antitrust infringements, this can only occur if three conditions are met: the remedy must be proportionate, necessary and effective ${ }^{84}$; second in the context of formal settlements under Article 9 of Regulation 1/2003 the CFI has held that the commitments must be proportionate, that is they do not go beyond that which is necessary to remedy the anticompetitive risk; 85 finally in the field of merger control the CFI and ECJ have taken the view that proportionality also applies when considering the Commission's acceptance of commitments. ${ }^{86}$ Proportionality means that the measures adopted must not exceed the limits of what is appropriate and necessary to attain the relevant objective and the least onerous remedy must be selected. However, if in a merger case the parties offer a set of commitments that is more than necessary to resolve the competition problem at hand, then the Commission is not bound to advise the parties that fewer commitments would suffice, the Commission merely judges whether the commitments solve the problem. ${ }^{87}$ It suggests that 'proportionality' is a criterion that applies to the offers made by the parties, not to the Commission decision. Therefore, as AG Kokott notes, '[e]xtraordinary circumstances would therefore have to exist before it could be accepted that a Commission decision based on voluntary commitments given by the undertakings concerned is not compatible with the principle of proportionality. ${ }^{98}$ Matters might be different if the parties offering commitments were arbitrarily forced to make certain commitments which turned out to be disproportionate; 89 this for example was what seems to have occurred in Alrosa. Drawing these disparate strands together, there seems some scope for challenging regulatory antitrust as shown in the Gasprom/ENI settlement on the basis that the remedy is unnecessarily wide. However, it is not particularly clear how far 'proportionality' can serve as a tool to thwart regulatory antitrust. For starters, any legal challenge requires a complainant, and when the Commission settles with the parties, it is unlikely that they will challenge the result. As settlements normally improve market access for competitors, there is no likely challenge from that quarter either. Accordingly the Commission retains the upper hand. Moreover, even when an appeal is heard, it is unlikely that the Courts will reject the Commission's stance, first because in many cases it is the parties who 'agree' to make concessions, and second even when they don't a decision will only be quashed if it is patently disproportionate, leaving a wide margin of discretion to the Commission.

\footnotetext{
84 Article 7 Regulation 1/2003. See G. Monti, n 16 above, 336-7; A. Tajana If Had a Hammer... Structural remedies and Abuse of Dominant Position' (2006) 1 Competition and Regulation in Network Industries 3.

${ }^{85}$ Case T-170/06 Alrosa v Commission, judgment of 11 July 2007.

${ }^{86}$ Case T-177/04 easy]et at [133-134]; Case T-202/02 Cementboun judgment of 23 February 2006 at [306-

320] (Affirmed on appeal, Case C-202/06 judgment of 17 December 2007).

87 [Case T-202/02 at 308].

88 [Case C-202/06 at 69].

89 [Case T-202/02 at 319].
} 
In spite of the limitations of using the principle of proportionality to curtail the antitrust powers of the Commission, it may be argued that if one wishes to insist upon the parallel application of EC competition law and sector specific regulation, that then the overlap between the two fields should be reduced by challenging antitrust decisions that appear regulatory. This sentiment was expressed in Scalia J in refusing to apply S.2 Sherman Act in a regulatory manner:

The 1996 Act is in an important respect much more ambitious than the antitrust laws. It attempts 'to eliminate the monopolies enjoyed by the inheritors of AT\&T's local franchises.' Section 2 of the Sherman Act, by contrast, seeks merely to prevent unlawful monopolization. It would be a serious mistake to conflate the two goals. The Sherman Act is indeed the 'Magna Carta of free enterprise,' but it does not give judges carte blanche to insist that a monopolist alter its way of doing business whenever some other approach might yield greater competition..$^{90}$

One surprising matter is how this view is shared both by those on the 'right' (e.g. the author of the quote) and those supposedly on the 'left' (e.g. Professor Hovenkamp) of the antitrust debate. ${ }^{91}$ The opposition to regulatory antitrust is much weaker in the EU, nevertheless its continued application risks undermining national regulatory efforts further because it gives the Commission wide powers to intervene even when there is no breach of the antitrust laws. In sum it is unlikely that regulatory antitrust will go away, and so the size of the overlap between competition and regulation remains significantly larger than in the United States.

\section{WAYS FORWARD}

The consensus view seems to be that less regulation and more antitrust is better. This view reflects that taken in the United States since the late 1970s when there was a reaction against the cost and ineffectiveness of regulation. ${ }^{92}$ In America, this might be acceptable in that antitrust is primarily litigation-based and prodefendant. In the EC, however, the 'less regulation and more antitrust' aphorism does not have the same impact at present, given the slowness by which utilities markets move from monopoly to competition, and the concomitant need for aggressive regulation. Nevertheless even the EU's de-regulatory strategy is designed to phase out regulation once competitive markets have been established. Moreover, the aggressive stance taken by the Commission in stating that EC competition law always applies even in the presence of regulation can be justified

\footnotetext{
90540 US 398, 415-416.

${ }^{91}$ Hovenkamp, n 55 above, 377

${ }^{22}$ See generally S. Breyer, Regulation and Its Reform (Cambridge, MA: Harvard University Press, 1982); A.E. Kahn 'Deregulation: Looking backward and looking forward' (1990) 7 Yale Journal on Regulation 325.
} 
by the concern that utilities regulators in Europe are weak and that even with so much legislative input to liberalise and Europeanise markets, there are considerable national variations (even when Member States ostensibly comply with the EC Directives) ${ }^{93}$ that the tough application of competition law is necessary to liberalise utilities and attempt to create an internal market.

In this paper I have argued in favour of a qualification to this position: there should be instances where competition law gives way to regulation, either because suspending competition law can yield greater efficiency or because it can allow the pursuit of other non-economic policy objectives. If one agrees, then what ways forward might there be? One possible solution is for greater consultation among regulators and antitrust agencies. Normally networks of regulators are seen as avenues to ensure uniformity and consistency in regulatory approach; but they can easily serve to allow arrangements whereby DG Competition is consulted and will not intervene to frustrate the objectives of national regulation. The problem is that this 'soft law' approach does not constrain national courts (not does it guarantee consistency of response from DG competition) and so would need to be complemented by the development of a hard law principle that can be applied by courts when the application of competition law would frustrate regulatory policy. The sort of doctrine I suggest is akin to that applicable in negligence law, where the courts have developed a principle whereby the claimant is unable to seek damages for negligence if that action would 'cut across' an existing regulatory framework. That is, if the court feels that tort liability would skew the regulatory balance that has been struck, then liability is not imposed. ${ }^{94}$ Negligence law in its modern form developed at the end of the Nineteenth Century at a time of sparse regulation (similar to the Sherman Act in 1890), the concern that negligence liability would cut across other spheres of regulation was not as urgent when the tort of negligence was consolidated by Lord Atkin in 1932; 95 rather it emerged as a response to the growth of regulation in the 1980s. Similarly, antitrust cuts across all economic sectors unless specifically excluded, and a similar judicial doctrine might help prevent its application when it would frustrate the achievement of policy goals pursued by other regulators. This suggestion may be implemented by extending the rationale behind the judgments of the court in Wouters and Meca Medina which seem to allow the non-application of competition law when this might damage certain other valued public interest considerations. ${ }^{96}$ The Lisbon Agenda's focus on competitiveness, the Reform Treaty's de-emphasis on competition as a key principle, plus the related calls for a greater emphasis on

\footnotetext{
${ }^{93}$ See for example J. Jordana, D. Levi-Faur, and I. Puig 'The Limits of Europeanization: Regulatory Reforms in the Spanish and Portuguese Telecommunications and Electricity Sectors' (2005) European Integration online Papers (EIoP), European Community Studies Association Austria (ECSA-A), vol. 9, 07.

${ }^{94}$ For a particularly good example, see Marc Rich v Bishop Rock Marine [1996] AC 211; see generally W.V.H. Rogers, Winfield and Jolowicz, on Tort (London: Sweet \& Maxwell, 17th ed, 2006) 155-158; D. Howarth, Textbook on Tort (London: Butterworths, 1995) 229-234.

95 In the seminal judgment Donoghue v Stevenson [1932] AC 502.

${ }^{96}$ Case C-309/99 Wouters [2002] ECR I-1577; Case C-519/04 P. Meca-Medina [2006] ECR I-6991.
} 
solidarity, ${ }^{97}$ combined with the policy arguments canvassed here, combine to suggest that consideration should be given to developing ways to restrict the application of competition law in those limited circumstances where the Community interest is best pursued by other means.

${ }^{97}$ M. Ross 'Promoting Solidarity: From Public Services to a European Model of Competition?' (2007) 44 Common Market Law Review 1057. 